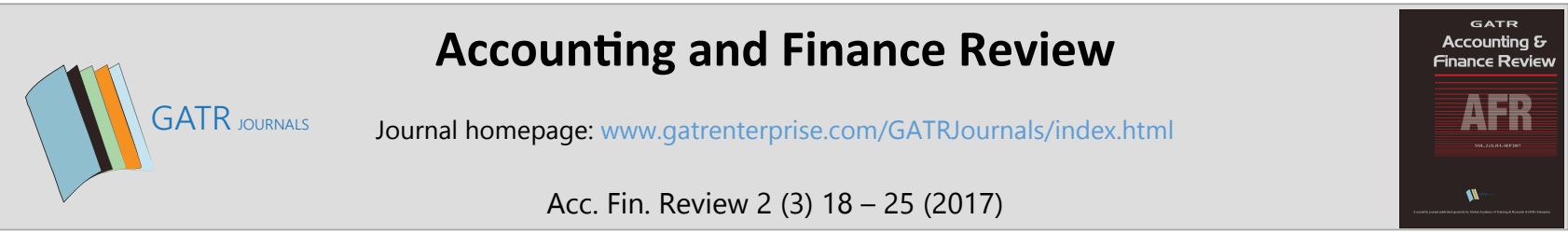

\title{
Factors Affecting Dividend Policy on Non-Financial Companies in Indonesia
}

\author{
Novia Wijaya ${ }^{1 *}$ and Agathon Felix ${ }^{2}$ \\ ${ }^{1,2}$ Trisakti School of Management, Indonesia
}

\begin{abstract}
Objective - The objective of this study is to obtain empirical evidence and analyse the factors that affect the dividend policy of non-financial firms listed on the Indonesian Stock Exchange. The factors studied include liquidity, leverage, growth, price/earnings, size, earnings per share, price to book ratio, ownership, age of the firm, floating rate, profitability, and free cash flow.

Methodology/Technique - The sampling method used in this study is purposive sampling, in which the samples are taken based on suitable characteristics of the population to generate representative samples. The total number of samples in this study are 105 non-financial firms listed on the Indonesian Stock Exchange between 2011 and 2015. The hypothesis is tested by using multiple regression analysis.

Findings - The results of this study show that earnings per share, price to book ratio, and floating rate affect the dividends policy while liquidity, leverage, growth, price/earnings, size, ownership, age of the firm, profitability, and free cash flow has no effect on dividend policy.

Novelty - The study findings contribute the companies to establish an appropriate dividend policy to satisfy the interest of both parties that is companies future growth and its investors.
\end{abstract}

Type of Paper: Empirical

Keywords: Dividend Policy; Price to Book Ratio; Ownership; Age of the Firm; Floating Rate; Free Cash Flow. JEL Classification: G32, G35, M41.

\section{Introduction}

With the tightening of global competition and a company's role as a back bone of a country's economy, there are now more companies registered on the Indonesian Stock Exchange providing an Initial Public Offering. Investors that have already invested their money into a company certainly want a higher return for the money they have invested through their dividends. On the other hand, the company certainly has a goal to survive (going concern) and continue to grow, so the decision to distribute dividends needs to be carefully considered, as it can inhibit growth and threaten the survival of a company.

Any changes associated with the dividend policy of a company will have a contradictive implication. If the company sets out all earnings for paying dividends, retained earnings will be depleted and the company's

\footnotetext{
* Paper Info: Received: February 15, 2017

Accepted: July 20, 2017

* Corresponding author:

E-mail: Novia@stietrisakti.ac.id

Affiliation: Trisakti School of Management, Indonesia.
} 
operations could be disrupted in the future. Conversely, if all earnings are retained, then the interests and expectations of the investors will be neglected. To satisfy the interest of both parties, the company must establish an appropriate dividend policy. An appropriate dividend policy is a dividend payout ratio that is determined by looking at the opportunity to invest available funds compared with expected dividend by the investors. The dividend policy is expected to create a balance between the current dividends to the company's growth in the future, in order to maximize stock price.

\section{Literature Review}

\subsection{The Bird in the Hand Theory}

This theory states that retained earnings will fall due to the increased payment of dividends, where investors prefer higher dividends than capital gains. This is because it in uncertain whether investors will receive the increase in capital gains in the future, so investors choose a more definitive dividend to minimize the risk (Gordon \& Walter, 1963 in Rafique, 2012).

\subsection{Agency Theory}

Jensen and Meckling (1976) state that there are conflicts that arise between investors and agents where managers in a company have the opportunity to make decisions or policies that benefit themselves, at the expense of the interests of the investors.

\subsection{Prior Empirical Study}

According to Deitiana (2009), liquidity does not affect the dividend policy.: this is in line with research conducted by Kuzucu (2015) along with Mardaleni (2014). This shows that liquidity does not affect a number of dividends paid. According to Kuzucu (2015), leverage does affect the dividend policy: this is in line with research conducted by Mawardi and Ratnadi (2014) along with Ahmad and Wardhani (2014). According to Lopolusi (2013), growth also affects the dividend policy: this is in line with research conducted by Kuzucu (2015). According to Kuzucu (2015), price/earnings affect the dividend policy: this is in line with research conducted by Abdullah and Agaki (2014). According to Dewi (2008), size affects the dividend policy: this is in line with research conducted by Kuzucu (2015) and Lopolusi (2013), along with Ilmiah and Asandimitra (2014). According to Abdullah and Agaki (2014), earnings per share affects the dividend policy: this is in line with research conducted by Kuzucu (2015). According to Abdullah and Agaki (2014), price to book ratio affects the dividend policy. Meanwhile, according to Kuzucu (2015) along with Ilmiah and Asandimitra (2014), price to book ratio does not affect the dividend policy. According to Kuzucu (2015), ownership affects the dividend policy. Meanwhile, according to Lucyanda and Lilyana (2012), ownership does not affect the dividend policy. According to Kuzucu (2015), the age of the firm affects the dividend policy. According to Kuzucu (2015), floating rate does not affect the dividend policy. According to Halim (2013), profitability affects the dividend policy: this is in line with the research conducted by Deitiana (2009). According to Rosdini (2009), free cash flow affects the dividend policy: this is in line with research conducted by Prasetio and Suyono (2016) and Lopolusi (2013) along with Lucyanda and Lilyana (2012).

\section{Methodology}

The research uses multiple regression methods to examine the influence of independent variables on the dependent variable. Furthermore, a classical assumption test is conducted before explaining the interpretation of the final results. The classical assumption test consists of a multicollinearity test, an autocorrelation test, and a heteroscedasticity test. The entire test is done by using IBM SPSS 19 software. The independent variables include liquidity, leverage, growth, price/earnings, size, earnings per share, price to book ratio, ownership, the 
age of the firm, floating rate, profitability, and free cash flow. Meanwhile, the dependent variable is dividend policy.

The populations of the research objects are nonfinancial companies that are listed on the Indonesian Stock Exchange. The sample selection uses a purposive sampling method. The purposive sampling method is used in stages and specific criteria are applied to determine the sample. The criteria that must be met by the sample used in this research are: (1) Non-financial company that consistently listed on the Indonesian Stock Exchange from 2011 to 2015; (2) Non-financial company that publish financial statements ending on December 31 between 2011 and 2015; (3) Non-financial company that publish the financial statements using Rupiah currency between 2011 and 2015; (4) Non-financial company that pays dividends from the profit between 2012 and 2014; and (5) Data needed in this research from 2011 to 2015 is available.

\subsection{Hypotheses and Definition of Variables}

Table 1. Definitions of Variables

\begin{tabular}{|c|c|c|}
\hline Variables & Description & Name \\
\hline Dividend Policy & Dividend Payout/Net Earnings & DPR \\
\hline Liquidity & Current Assets/Current Liabilities & CR \\
\hline Leverage & Total Liabilities/Total Assets & DA \\
\hline Growth & $\frac{\text { Total Assets }}{\text { Total Assets }_{t-1}-\text { Total Assets }_{t-1}}$ & GROW \\
\hline Price/Earnings & Price of the Stock/EPS & $\mathrm{PE}$ \\
\hline Size & The Natural Log of Total Assets & SIZE \\
\hline Earnings per share & Net Earnings/The Number of Shares Outstanding & EPS \\
\hline Price to Book Ratio & Market Capitalization/Book Value & $\mathrm{PB}$ \\
\hline Ownership & $\begin{array}{l}0=\text { Company that do not have family ownership } \\
1=\text { Company that have family ownership }\end{array}$ & OWN \\
\hline Age of The Firm & Current Year - Establishment Year of the Firm & AGE \\
\hline Floating Rate & $\begin{array}{l}\text { The Number of Freely Traded Shares } \\
\text { Total Number of shares outstanding }\end{array}$ & FLO \\
\hline Profitability & Net Income/Total Assets & ROA \\
\hline Free Cash Flow & $\begin{array}{l}\text { Operating Cash Flow - Net Capital Expenditures + } \\
\text { Changes in Net Working Capital }\end{array}$ & FCF \\
\hline
\end{tabular}

Stock dividends are beyond the scope of this research. Liquidity is measured by the current ratio. The firm liquidity is expected to affect dividends because dividends must be paid out in cash. Firms with greater liquidity are expected to pay out more dividends (Kuzucu, 2015). This variable was measured using the measurement used in research conducted by Kuzucu, 2015. Therefore, it is hypothesized that liquidity affects dividend policy.

Leverage is measured by a debt to total assets ratio. Highly leveraged firms pay lower dividends because they have to put the interest of creditors at the forefront (Kuzucu, 2015). This variable was measured using the measurement used in research conducted by Kuzucu, 2015. Therefore, it is hypothesized that leverage affects dividend policy.

High growth firms pay lower dividends because they need more funds to finance their growth. As they grow, they will then allocate their financial resources to making further investments (Kuzucu, 2015). This variable was measured using the measurement used in research conducted by Samrotun, (2015). Therefore, it is hypothesized that growth affects dividend policy.

Price/earnings ratio is used to measure how much an investor has to pay for each rupiah of the firm's revenue. In other words, this ratio indicates the level of confidence of investors in the future performance of the company (Gitman \& Zutter, 2015). This variable was measured using the measurement used in research conducted by Kuzucu, 2015. Therefore, it is hypothesized that price/earnings affect dividend policy. 
The size of a firm has an important role to play in explaining the dividend payout ratio: the larger the firm, the easier it is for them to access the capital markets (Nuringsih, 2005). This variable was measured using the measurement used in research conducted by Kuzucu, (2015). Therefore, it is hypothesized that the size of the firm affects dividend policy.

Earnings per share are the revenue from any number of shares outstanding, which reflects the firm's ability to pay dividends (Deitiana, 2009). A firm's earnings are expected to be positively associated with the payment of dividends since a firm with positive earnings is expected to pay dividends (Kuzucu, 2015). This variable was measured using the measurement used in research conducted by Kuzucu (2015). Therefore, it is hypothesized that earnings per share affect dividend policy.

Price to book ratio is the ratio that shows the level of investment opportunity in the firm. Firms with a higher price to book ratio are expected to pay fewer dividends (Marpaung \& Hadianto, 2009). This variable was measured using the measurement used in research conducted by Kuzucu, (2015). Therefore, it is hypothesized that price to book ratio affects dividend policy.

Firms controlled by family members have lower agency costs because they do not need to hire professionals to run their firms (Kuzucu, 2015). According to Shleifer and Vishny (1986), firms with family ownership tend not to distribute dividends in large numbers because of the concentration of ownership. This variable was measured using the measurement used in research conducted by Kuzucu, (2015). Therefore, it is hypothesized that ownership affects dividend policy.

The age of a firm has an impact on the firm's ability to pay dividends. Low growth stage firms are likely to pay higher dividends, since steady firms only need a small investment fund so that the company has a high cash flow to pay dividends to the investors (Grullon et al., 2002). This variable was measured using the measurement used in research conducted by Kuzucu, (2015). Therefore, it is hypothesized that the age of a firm affects dividend policy.

La Porta et al. (2000) reveals that minority shareholders expect a higher dividend from the firm and they will use their voting rights to receive dividends under the agency conflict. Thus, people in the company use high dividends to attract minority shareholders. If the composition of the shareholders in a firm is equal, then the dividend to be paid tends to be high because the power of the minority shareholders is equal to that of the majority shareholders. This variable was measured using the measurement used in research conducted by Kuzucu, (2015). Therefore, it is hypothesized that floating rate affects dividend policy.

Profitability is a firm's ability to generate profits by using company assets, both current assets, and fixed assets, the ability of the company to produce a product or service, as well as to add value to an existing product. Profitability is closely associated with the dividend policy of a company because if profits are high, the dividends to be distributed are also high (Gitman \& Zutter, 2015). This variable was measured using the measurement used in research conducted by Halim, (2013). Therefore, it is hypothesized that profitability affects dividend policy.

According to Gitman and Zutter (2015), free cash flow indicates how much of the amount of cash is available to investors and creditors after the company covers all the operating costs of the company and investments in fixed assets and current assets. Associated with the conflict of the agency, managers are believed to waste available free cash flow on investments that are not needed by the company so the free cash flow is available for dividend payments to investors. This variable is measured using the measurement used in research conducted by Lopolusi, 2013. Therefore, it is hypothesized that free cash flow affects dividend policy.

\section{Results}

\subsection{Sample set}

The non-financial data is obtained from the archive on the website of the Indonesia Stock Exchange (IDX). Financial ratios were calculated by using the financial information of a firm's audited financial statements. Dividend pay-outs ratio during the three-year period between 2012 and 2014 on the IDX are also examined. 
This means that the earnings and the financial reports of the fiscal years between 2011 and 2015 are used in the research. Financial sector firms, including banks, insurance companies, holdings and investment trusts, are excluded from the data set as they have different financial structures and bookkeeping practices according to the different nature of their business. Thus, a data set which covers 304 firm-year observations from 103 firms is obtained. The summary statistics of the sample set are presented in Table 2 and the frequency distributions of ownership are presented in Table 3.

Table 2. Summary statistics

\begin{tabular}{|l|c|l|l|l|l|}
\hline Variable & \multicolumn{1}{|c|}{ N } & \multicolumn{1}{|c|}{ Minimum } & \multicolumn{1}{|c|}{ Maximum } & \multicolumn{1}{c|}{ Mean } & \multicolumn{1}{c|}{ Std. Deviation } \\
\hline DPR & 304 & -0.4122 & 1.0005 & 0.334356 & 0.2105084 \\
\hline CR & 304 & 0.3896 & 12.2281 & 2.385995 & 1.8034856 \\
\hline DA & 304 & 0.0699 & 0.8500 & 0.438156 & 0.1885486 \\
\hline GROW & 304 & -0.1196 & 0.8485 & 0.178403 & 0.1483079 \\
\hline PE & 304 & -86.9565 & 165.8333 & 17.574118 & 14.8753295 \\
\hline SIZE & 304 & 25.5796 & 33.0950 & 29.052497 & 1.5377989 \\
\hline EPS & 304 & -46 & 17782 & 686.69 & 2361.159 \\
\hline PB & 304 & 0.2246 & 53.5901 & 3.325842 & 5.2050507 \\
\hline OWN & 304 & 0 & 1 & 0.54 & 0.500 \\
\hline AGE & 304 & 7 & 95 & 37.75 & 13.549 \\
\hline FLO & 304 & 0.0067 & 0.8188 & 0.293546 & 0.1697524 \\
\hline ROA & 304 & -0.0029 & 0.4038 & 0.102289 & 0.0779594 \\
\hline FCF & 304 & $-6 . E 12$ & $2 . E 13$ & $4.98 \mathrm{E} 11$ & $2.647 \mathrm{E} 12$ \\
\hline
\end{tabular}

Table 3. Frequency distribution of ownership

\begin{tabular}{|l|c|c|}
\hline \multicolumn{1}{|c|}{ Explanations } & Frequency & Percentage \\
\hline Do not have family ownership & 141 & $46.4 \%$ \\
\hline Do have family ownership & 163 & $53.6 \%$ \\
\hline
\end{tabular}

\subsection{Residual normality test results}

Before testing the hypothesis, it is necessary to determine whether the data used in the research is normally distributed or not. A normality test is conducted by using the One Sample Kolmogorov- Smirnov test with $\alpha$ $=0.05$ to determine the normality of the data to be tested. With 304 data samples being observed, the significant value of the residual normality test is 0.496 . The conclusion is that the data is normally distributed because the significant value exceeds $\alpha$.

\subsection{Classical assumption test results}

Autocorrelation test in this research is done by using Bruesch-Godfrey test. The significant value of Bruesch-Godfrey test results is 0.207 . The conclusion is, there is no autocorrelation in the data of this research because the significant value exceeds $\alpha$. Heteroscedasticity test in this research is done by using Glejser test. The significant value of Glejser test for leverage (DA), growth (GROW), size (SIZE), earnings per share (EPS), price to book ratio (PB), ownership (OWN), age of the firm (AGE), profitability (ROA) and free cash flow (FCF) are exceed $\alpha$, this means there's no heteroscedasticity at those variables. Meanwhile, the significant value of Glejser test for liquidity (CR), price/earnings (PE), and floating rate (FLO) are below $\alpha$, this mean there's heteroscedasticity at independent variable liquidity (CR), price/earnings (PE), and floating rate (FLO). Based on the result of multicolinearity test, the tolerance value is exceeding 0.1 and VIF value is below 10 . This mean there's no multicolinearity at all independent variable. 


\subsection{Hypothesis test results}

According to the results of the test of the correlation coefficient, the value of $\mathrm{R}$ is 0.671 . This means that the correlation between the dependent variable and the independent variables are strong, because $\mathrm{R}$ value is greater than 0.5. Based on the results of the test of the determination coefficient, the value of R2 is 0.428 . This mean that variations of the dependent variable can be explained by variations of the independent variable by $42.8 \%$, while the remaining $57.2 \%$ are explained by other factors that are not included in this research model. $\mathrm{F}$ test is used to determine whether the regression model used in this research is appropriate or not. According to the results of the $\mathrm{F}$ test, the significant value is 0.000 which means the significant value is less than 0.05 so it can be said that this regression model is appropriate.

Table 4. $\mathrm{t}$ test result

\begin{tabular}{|c|c|c|c|}
\hline Variable & B & Sig. & Explanations \\
\hline Constant & 0.119 & & \\
\hline CR & -0.008 & 0.286 & No effect \\
\hline DA & -0.023 & 0.774 & No effect \\
\hline GROW & -0.207 & 0.003 & Effect \\
\hline PE & 0.003 & 0.000 & Effect \\
\hline SIZE & 0.005 & 0.514 & No effect \\
\hline EPS & $1.922 E-5$ & 0.000 & Effect \\
\hline PB & 0.008 & 0.009 & Effect \\
\hline OWN & -0.033 & 0.097 & No effect \\
\hline AGE & 0.001 & 0.435 & No effect \\
\hline FLO & -0.104 & 0.098 & No effect \\
\hline ROA & 0.704 & 0.003 & Effect \\
\hline FCF & $5.738 E-15$ & 0.158 & No effect \\
\hline
\end{tabular}

Liquidity (CR), leverage (DA), size (SIZE), ownership (OWN), age of the firm (AGE), floating rate (FLO), and free cash flow (FCF) all have a significant value that is greater than $\alpha 0.05$, which means that liquidity, leverage, size, ownership, age of the firm, floating rate, and free cash flow do not affect the dividend policy. Meanwhile, growth (GROW), price/earnings (PE), earnings per share (EPS), price to book ratio (PB), and profitability (ROA) does affect dividend policy because the significant value for those variables is smaller than $\alpha 0.05$.

\section{Discussion}

The dividend behaviors of Indonesian listed firms are examined in this research in order to investigate the determinants of dividends. Excluding data of financial sector firms, the data of 304 firm-year payouts made by 103 firms during the period from 2012 to 2014 are included in the dataset. The hypothesis test results show that growth, price/earnings, earnings per share, price to book ratio, and profitability do affect dividend policy. Meanwhile, liquidity, leverage, size, ownership, the age of the firm, floating rate, and free cash flow does not affect dividend policy.

\section{Acknowledgements}

I give my thanks to my family and all of my friends that always support me, also Novia Wijaya, S.E., M.Si. from Trisakti School of Management as my mentor for her guidance during this study. 


\section{References}

Abdullah, H., \& Agaki, R. F. (2014). Pengaruh Earning Per Share, Price Earning Ratio Dan Price to Book Value Terhadap Dividend Payout Ratio Pada Perusahaan Pertambangan Yang Terdaftar Di Bei Periode 2008-2011 [Earning Effect Per Share, Price Earning Ratio And Price to Book Value to Dividend Payout Ratio in Mining Company Listed in Idx Period 2008-2011]. Dinamika Ekonomi-Jurnal Ekonomi dan Bisnis, 7(1).

Ahmad, G. N., \& Wardani, V. K. (2014). The Effect of Fundamental Factor to Dividend Policy: Evidence in Indonesia Stock Exchange. International Journal of Business and Commerce, 4(2), 14-25.

Deitiana, T. (2009). Faktor-Faktor yang Mempengaruhi Kebijakan Pembayaran Dividen Kas [Factors Affecting the Cash Dividend Payment Policy]. Jurnal Bisnis dan Akuntansi, 11(1), 57-64.

Dewi, S. C. (2008). Pengaruh Kepemilikan Managerial, Kepemilikan Institusional, Kebijakan Hutang, Profitabilitas dan Ukuran Perusahaan terhadap Kebijakan Dividen [The Influence of Managerial Ownership, Institutional Ownership, Debt Policy, Profitability and Company Size on Dividend Policy]. Jurnal Bisnis dan Akuntansi, 10(1), 47-58.

Gitman, L. J., \& Zutter, C. J. (2015). Principles of Managerial Finance. 14th Edition. Edinburgh: Pearson.

Grullon, G., Michaely, R., \& Swaminathan, B. (2002). Are dividend changes a sign of firm maturity?. The Journal of Business, 75(3), 387-424.

Halim, J. J. (2013). Faktor-faktor Yang Mempengaruhi Kebijakan Dividen Perusahaan Yang Terdaftar Di Bursa Efek Indonesia Pada Sektor Industri Barang Konsumsi Periode 2008-2011 [Factors Affecting the Company's Dividend Policy Listed In Indonesia Stock Exchange On Consumer Goods Industry Sector Period 2008-2011]. Retrieved from: repository.ubaya.ac.id

Ilmiah, H. \& Asandimitra, N. (2014) Pengaruh Profitabilitas, Firm Size, Mtbv, Arus Kas Dan Pertumbuhan Penjualan Terhadap Kebijakan Dividen Pada Perusahaan Sektor Keuangan Di Bursa Efek Indonesia [Effect Of Profitability, Firm Size, Mtbv, Cash Flow And Sales Growth Of Dividend Policy In Financial Sector Company In Indonesia Stock Exchange]. Jurnal Ilmu Manajemen, 2(2) 574-585

Indonesia Pada Sektor Industri Barang Konsumsi Periode 2008-2011 [Factors Affecting Dividend Policy of Companies Listed In Indonesia Stock Exchange On Consumer Goods Industry Sector Period 2008-2011.].

Jensen, M. C., \& Meckling, W. H. (1976). Theory of the firm: Managerial behavior, agency costs and ownership structure. Journal of financial economics, 3(4), 305-360.

Kuzucu, N. (2015). Determinants of Dividend Policy: A Panel Data Analysis for Turkish Listed Firms.

La Porta, R., Lopez-de-Silanes, F., Shleifer, A., \& Vishny, R. W. (2000). Agency problems and dividend policies around the world. The journal of finance, 55(1), 1-33.

Lopolusi, I. (2013). Analisis Faktor-faktor yang Mempengaruhi Kebijakan Dividen Sektor Manufaktur yang terdaftar Di PT. Bursa Efek Indonesia Periode 2007-2011 [Analysis of Factors Affecting Dividen Sector Policy Manufactured at PT. Indonesia Stock Exchange Period 2007-2011]. Jurnal Ilmiah Mahasiswa Universitas Surabaya, 2(1), 18-24.

Lucyanda, J. \& Lilyana. (2012). Pengaruh Free Cash Flow dan Struktur Kempemilikan Terhadap Dividend Payout Ratio. Jurnal Dinamika Akuntansi, 4(2).

Mardaleni. (2014). Analisis Pengaruh Return on Equity, Debt Equity Ratio dan Current Ratio terhadap Dividen Payout Ratio pada Perusahaan Property dan Real Estate yang Terdaftar di Bursa Efek Indonesia periode 2010-2012. EJurnal Apresiasi Ekonomi, 2(2), 73-79.

Marpaung, E. I., \& Hadianto, B. (2011). Pengaruh Profitabilitas dan Kesempatan Investasi terhadap Kebijakan Dividen: Studi Empirik pada Emiten Pembentuk Indeks LQ45 di Bursa Efek Indonesia [The Effect of Profitability and Investment Opportunity on Dividend Policy: Empirical Study on LQ45 Index Shares Issuer in Indonesia Stock Exchange]. Jurnal Akuntansi, 1(1), p-70.

Mawarni, L. F. I., \& Ratnadi, N. M. D. (2014). Pengaruh Kesempatan Investasi, Leverage, dan Likuiditas pada Kebijakan Dividen Perusahaan Manufaktur yang terdaftar di BEI [Influence of Investment Opportunity, Leverage, and Liquidity on Dividend Policy of Manufacturing Company listed on BEI]. E-Jurnal Akuntansi, 9(1), 200-208.

Nuringsih, K. (2005). Analisis Pengaruh Kepemilikan Manajerial, Kebijakan Utang, ROA dan Ukuran Perusahaan Terhadap Kebijakan Dividen: Studi 1995-1996 [Analysis of the Effect of Managerial Ownership, Debt Policy, ROA and Company Size on Dividend Policy: Study 1995-1996]. Jurnal Akuntansi dan Keuangan Indonesia, 2(2), $103-123$.

Prasetio, D. A., \& Suyono, B. (2016). Pengaruh Profitabilitas, Free Cash Flow, Investment Opportunity Set terhadap Dividend Payout Ratio. Jurnal Ilmu dan Riset Akuntansi, 5(1). 
Rafique, M. (2012). Factors affecting dividend payout: Evidence from listed non-financial firms of Karachi stock exchange. Business Management Dynamics, 1(11), 76-92.

Rosdini, D. (2009). Pengaruh Free Cash Flow Terhadap Dividend Policy. Abstrak.

Samrotun, Y. C. S. (2015). Kebijakan Dividen Dan Faktor-Faktor Yang Mempengaruhinya [Dividend Policy And Factors That Influence It]. Paradigma, 13(01), 92-103.

Shleifer, A., \& Vishny, R. W. (1986). Large shareholders and corporate control. Journal of political economy, 94(3), 461488. 